\title{
Zygosaccharomyces gambellarensis sp. nov., an ascosporogenous yeast isolated from an Italian 'passito' style wine
}

Correspondence

Sandra Torriani

sandra.torriani@univr.it

\author{
Sandra Torriani, Marilinda Lorenzini, Elisa Salvetti and Giovanna E. Felis
}

Department of Biotechnology, University of Verona, Strada le Grazie 15, 37134 Verona, Italy

\section{INTRODUCTION}

Vin Santo of Gambellara is a traditional sweet white wine obtained from off-vine overripened grapes of the Garganega variety that is produced in a small area (less than $40 \mathrm{~km}^{2}$ ) of the Veneto region (north-east of Italy). This wine obtained the specificity of Controlled Designation of Origin by the Italian government in 1970 (Gazzetta Ufficiale della Repubblica Italiana, 1970), which implies that its distinctive sensorial characteristics are derived from local environmental factors, as well as the particular winemaking procedure. In fact, the winemaking process includes many peculiar steps that have remarkable effects on the microbial population and, thus, on the wine properties. Briefly, grapes are partially dried in attics for 5/6 months; during this phase, saprophytic moulds, including Botrytis cinerea (noble rot), grow on the grapes and contribute positively to the chemical and sensory characteristics of the final product. Wine pressing is generally carried out during the Easter period and must fermentation proceeds very slowly as sugar levels are $\leqslant 350 \mathrm{~g} \mathrm{l}^{-1}$, reaching approximately 14 alcoholic degrees. The wine is aged for two or more years in oak barrels or barriques.

Few microbiological studies have been carried out on sweet white wines from partially dried grapes (e.g. Fleet et al., 1984; Donèche, 1993; Fleet, 1998; Mills et al., 2002). These

Abbreviation: RAPD, Randomly amplified polymorphic DNA.

The GenBank/EMBL/DDBJ accession numbers for the partial 265 rRNA gene sequence of strains ZOO3-5 ${ }^{\top}$, CA06-8 and ME06-9 are FR725931, FR725932 and FR725933, respectively.

Two supplementary figures are available with the online version of this paper. studies have shown that osmotolerant non-Saccharomyces yeasts are commonly found at the beginning of the fermentation, but they decrease as Saccharomyces species start dominating the process. However, some of the nonSaccharomyces species, such as Candida spp., Dekkera spp., Hansenula spp., Kloeckera spp., Kluyveromyces spp., Pichia spp. and Zygosaccharomyces spp. can survive and they can still be present during storage and ageing of wine, thus having an impact on the final wine quality (RibereauGayon et al., 2006; Ciani et al., 2010; Parapouli et al., 2010). In particular, Zygosaccharomyces show peculiar features including specific nutritional requirements in terms of sugars (e.g. fructophily), osmotolerance, formation of heatresistant ascospores and resistance to preservatives such as sulphite, sorbic acid and ethanol. Interestingly, these yeasts, even if often associated with wine spoilage (Fugelsang, 1996; Stratford, 2006), could also have a positive role in fermentation processes (Jolly et al., 2006).

Considering natural selection and the progressive adaptation of micro-organisms to the climatic and physicochemical conditions of the habitat, which create an ecological niche unique for every kind of wine-making, a study of the indigenous eukaryotic microbiota of Vin Santo of Gambellara was undertaken. During such analysis, 25 isolates were characterized from three wine samples produced in different vintages and diverse wineries. Isolates were shown to belong to the genus Zygosaccharomyces by cell morphology and asci formation (Kurtzman \& Fell, 1998), but could not be allocated to any previously described species, i.e. Zygosaccharomyces bailii, Z. bisporus, Z. kombuchaensis, Z. lentus, $Z$. mellis, Z. machadoi and Z. rouxii (Kurtzman, 2003; Rosa \& Lachance, 2005). Therefore, in the present study, 
three representatives of the 25 isolates, namely CA06-8, ME06-9 and ZO03- $5^{\mathrm{T}}$, were subjected to detailed molecular and physiological analysis. Based on results presented, a novel species is proposed.

\section{METHODS}

Yeast strains. Yeast strains were isolated from Vin Santo of Gambellara produced in three different wineries during diverse vintages. Wine samples were collected from oak barrels during ageing and either directly plated or first centrifuged at $8000 \mathrm{~g}$ for $10 \mathrm{~min}$ prior to transfer onto two selective cultivation media: Wallerstein laboratory nutrient agar (WL; Oxoid), supplemented with biphenyl (150 $\mathrm{mg} \mathrm{1}^{-1}$; Sigma) and chloramphenicol (100 $\mathrm{mg} \mathrm{l}^{-1}$; Sigma); and tryptone-glucose-yeast extract (TGY) agar (Beuchat, 1993). After incubation for 5 days at $27{ }^{\circ} \mathrm{C}$, individual colonies were isolated and purified through repeated streaking. Isolates were maintained on yeast extract-peptone-glucose (YEPD; $10 \mathrm{~g}$ yeast extract $1^{-1}, 20 \mathrm{~g}$ peptone $1^{-1}$ and $20 \mathrm{~g}$ glucose $\mathrm{l}^{-1}$ ) agar slants prepared with $15 \mathrm{~g}$ agar $1^{-1}$ and kept at $4{ }^{\circ} \mathrm{C}$ before preservation by freeze-drying. Yeast isolates were routinely subcultured in YEPD at $27^{\circ} \mathrm{C}$ for $72 \mathrm{~h}$ on a rotary shaker (200 r.p.m.).

Phenotypic characterization. The isolates were characterized following the usual criteria for spore formation and physiological tests according to Yarrow (1998). Sugar fermentation and assimilation tests were also performed using the API 20C AUX strip system (bioMérieux).

The effects of various conditions on growth were examined in test tubes containing $10 \mathrm{ml}$ liquid medium, which were inoculated with about $10^{5}$ cells $\mathrm{ml}^{-1}$. Tubes were incubated under both static and shaking conditions (200 r.p.m.) for 13 days.

The ability of the isolates to grow at different temperatures, i.e. 4, 8, 16, $20,27,34,37$ and $40{ }^{\circ} \mathrm{C}$, was evaluated using YEPD broth. To test the effect of high sugar concentrations on growth, YEPD medium was supplemented with different amounts of glucose (200 and $\left.400 \mathrm{~g} \mathrm{l}^{-1}\right)$ and incubated at $27{ }^{\circ} \mathrm{C}$. Growth in modified YEPD (mYEPD), which lacked glucose and contained fructose $\left(20 \mathrm{~g} \mathrm{l}^{-1}\right)$, was also examined at $27{ }^{\circ} \mathrm{C}$. The increase in cell number was monitored by measuring $\mathrm{OD}_{600}$.

DNA extraction, PCR and sequence analysis. Genomic DNA was extracted from overnight cultures applying the protocol of mechanical cell disruption as described by Cocolin et al. (2000). The obtained genomic DNA was suspended in $50 \mu \mathrm{l}$ TE buffer $(10 \mathrm{mM}$ Tris/ $\mathrm{HCl}, 1 \mathrm{mM}$ EDTA, $\mathrm{pH} 8$ ) and maintained at $-20{ }^{\circ} \mathrm{C}$.

Randomly amplified polymorphic DNA (RAPD)-PCR fingerprinting of the isolates was carried out using primer M13 (5'-GAGGGTGGCGGTTCT-3') as described previously (Tofalo et al., 2009). Conversion, normalization and numerical analysis of the patterns were performed using the software GelCompar 4.0 (Applied Maths, Kortrijk, Belgium).

The D1/D2 domain of the 26S rRNA gene was amplified according to Kurtzman \& Robnett (1998) using primers NL1/NL4; the applied thermal cycling program comprised initial denaturation at $94{ }^{\circ} \mathrm{C}$ for $5 \mathrm{~min}$, then 36 cycles at $94{ }^{\circ} \mathrm{C}$ for $1 \mathrm{~min}, 52{ }^{\circ} \mathrm{C}$ for 2 min and $72{ }^{\circ} \mathrm{C}$ for $2 \mathrm{~min}$, followed by a final extension at $72{ }^{\circ} \mathrm{C}$ for $10 \mathrm{~min}$.

Amplicons were purified using the NucleoSpin Extract II (MachereyNagel) following the manufacturer's instructions and sequenced at the BMR Genomics sequencing facility (Padua, Italy) using the same primers used for amplification.

Sequence similarity searches were performed using the BLAST network service on the NCBI website (http://blast.ncbi.nlm.nih.gov/).
Sequence alignments were performed with CLUSTAL W 2.0 (Larkin et al., 2007) and adjusted manually. Phylogenetic analysis was performed using the software package MEGA4 (Tamura et al., 2007) using the Jukes-Cantor distance model, neighbour-joining (Saitou \& Nei, 1987) and minimum evolution (Nei \& Kumar, 2000) methods for tree reconstruction, as suggested by Kämpfer et al. (2003). Sequences from Saccharomyces cerevisiae and Wickerhamomyces anomalus (formerly 'Pichia anomala'; Kurtzman, 2011) were included as the outgroup.

The statistical reliability of the phylogenetic tree topology was evaluated using bootstrapping with 1000 replicates (Felsenstein, 1985).

\section{RESULTS AND DISCUSSION}

A low number of colonies with very similar morphology was detected from each sample of Vin Santo of Gambellara on the two cultivation media (WL and TGY), indicating the presence of osmophilic or osmotolerant yeast populations. Independent clones from samples from the three wineries were isolated: eight from cellar A, nine from cellar $\mathrm{B}$ and eight from cellar C.

The collection of 25 isolates was subjected to RAPD-PCR using primer M13 and numerical analysis of fingerprinting profiles was performed. The resulting dendrogram (Supplementary Fig. S1, available in IJSEM Online) revealed the presence of three different genomic clusters; three strains, i.e. ZO03- $5^{\mathrm{T}}$, ME06-9 and CA06-8, were chosen as representatives of each cluster and further analysed.

Firstly, the 26S rRNA gene D1/D2 domain was sequenced and analysed for each of the three strains. The amplified fragments had identical nucleotide sequences indicating their conspecificity. The phylogenetic relationship with all Zygosaccharomyces species, also including Zygosaccharomyces pseudorouxii as in Rosa \& Lachance (2005), revealed that strains ZO03-5 ${ }^{\mathrm{T}}$, ME06-9 and CA06-8 formed a distinct, highly supported clade with $Z$. machadoi, Z. mellis, $Z$. pseudorouxii and $Z$. rouxii (Fig. 1), with $Z$. machadoi as the closest relative. As for sequence similarity values, the selected strains and $Z$. machadoi showed differences in nine positions out of $423 \mathrm{nt}$ compared (2.1\%). Usually, $26 \mathrm{~S}$ rRNA gene D1/D2 domain sequences differing by more than $1 \%$ are considered indicative of different species (Kurtzman \& Robnett, 1998). Therefore, phenotypic and physiological analyses were performed to verify and support this hypothesis.

Growth in different environmental conditions was tested. When cultured in YEPD medium under static and shaking conditions, the novel strains showed a lag phase of about $46 \mathrm{~h}$. Also, a preference for aerobic conditions was observed, which is similar to other Zygosaccharomyces species, i.e. $Z$. rouxii, $Z$. bailii and $Z$. bisporus (Steels et al., 1999). This behaviour distinguishes the novel strains from $Z$. lentus, a species that is also characterized by a slow growth rate, but which does not grow in shake cultures with high levels of oxygen (Steels et al., 1999). 


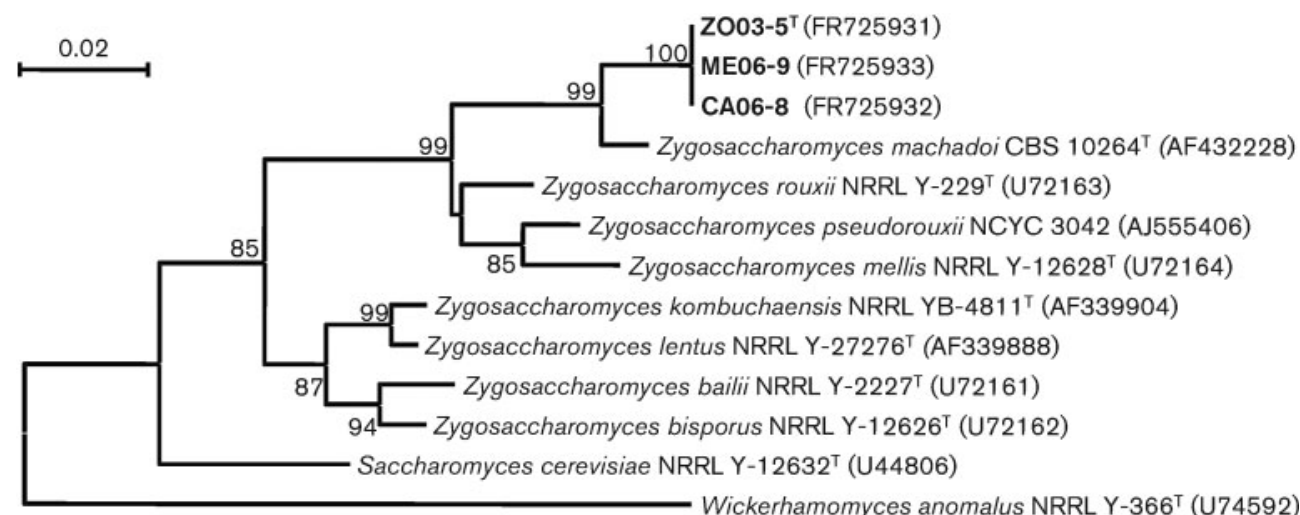

Fig. 1. Phylogenetic tree based on $26 \mathrm{~S}$ rRNA gene sequences depicting the relationship between strains $Z 003-5^{\top}, C A 06-8$ and ME06-9, and Zygosaccharomyces species; sequences from Saccharomyces cerevisiae and Wickerhamomyces anomalus were used as the outgroup. The tree was calculated using the Jukes-Cantor distance formula and minimum evolution algorithm. Bootstrap values (\%; 1000 replicates) are given at nodes (values below $60 \%$ are not shown). Bar, number of substitutions per site.

With regard to growth in the presence of different glucose concentrations, the three strains showed slow growth in the presence of 20 and $200 \mathrm{~g}$ glucose $1^{-1}$, whereas a higher sugar concentration $\left(400 \mathrm{~g} \mathrm{l}^{-1}\right)$ allowed faster growth. Growth kinetics of the novel isolates were similar in YEPD and $\mathrm{mYEPD}$, which contained fructose $\left(20 \mathrm{~g} \mathrm{l}^{-1}\right)$ instead of glucose, revealing they have no clear preference for either of the two sugars (Supplementary Fig. S2, available in IJSEM Online).

Finally, effects of temperature on growth were examined at $4,8,16,20,27,34,37$ and $40{ }^{\circ} \mathrm{C}$. Strains were unable to grow at 4,8 and $40{ }^{\circ} \mathrm{C}$ during the time period studied (13 days). This behaviour distinguishes these strains from $Z$. machadoi, a species with similar physiological characteristics: the novel isolates grew at $37^{\circ} \mathrm{C}$, whereas $Z$. machadoi was not able to develop at this temperature (Rosa \& Lachance, 2005).

In conclusion, phylogenetic analysis, phenotypic data and overall differences between the novel isolates and other Zygosaccharomyces species support the proposal for a novel osmophilic non-psychrophilic species, for which the name $Z$. gambellarensis is proposed, with $\mathrm{ZO} 03-5^{\mathrm{T}}(=\mathrm{CBS}$ $12191^{\mathrm{T}}=$ MUCL $53393^{\mathrm{T}}$ ) as the type strain.

\section{Latin diagnosis of Zygosaccharomyces gambellarensis Torriani, Lorenzini, Salvetti et Felis sp. nov.}

Cultura in extracto malti post 3 dies ad $27{ }^{\circ} \mathrm{C}$, cellulae ellipsoidae aut globosae $(5 \mu \mathrm{m})$, singulae, binae et fasciculatae, per gemmationem multipolarem reproducentes. Pseudohyphae et hyphae verae non fiunt post 15 dies ad $27{ }^{\circ} \mathrm{C}$ in medio agaro acetato formantur. Asci per conjugationem cellularum vegetativarum oriuntur, conjugati, 1-4 ascosporas ovales contenentes, non liberi. In WL post 7 dies ad $27{ }^{\circ} \mathrm{C}$, incrementum fuscum pallidum, nitens, butyrosum; margo uniformis. Glucosum et fructosum fermentantur at non sucrosum, maltosum nec trehalosum. Glucosum, glycerinum, D-sorbitolum, Dgalactosum, sucrosum, trehalosum, maltosum, adonitolum et D-xylosum assimilantur at non cellobiosum, lactosum, raffinosum, melezitosum, L-arabinosum, N-acetyl-D-glucosaminum, methylum $\alpha$-D-glucopyranosidum, inositolum, xylitolum, D-mannitolum, D-gluconatum sodicum, DL-lactatum, citratum, melibiosum, L-arabinosum, D-ribosum, L-rhamnosum, methanolum, ethanolum, meso-erythritolum nec 2-ketogluconatum calcicum. Crescit in medio cum $40 \%$ glucoso.

Typus depositus in collectionis Centraalbureau voor Schimmelcultures (CBS), cum numero CBS $12191^{\mathrm{T}}$ et in collectionis Mycothèque de l'Universite catholique de Louvain BCCM/ MUCL, cum numero MUCL $53393^{\mathrm{T}}$.

\section{Description of Zygosaccharomyces gambellarensis Torriani, Lorenzini, Salvetti \& Felis sp. nov.}

Zygosaccharomyces gambellarensis (gam.bel.la.ren'sis. L. adj. gambellarensis refers to the Gambellara area).

On $5 \%$ malt extract agar medium, after 3 days of incubation at $27{ }^{\circ} \mathrm{C}$, cells are spherical $(5 \mu \mathrm{m}$ diameter $)$ and occur singly, in pairs or in small groups. Budding is multilateral; budding cells remain attached to each other and often form a flower-like arrangement (Fig. 2a). Neither hyphae nor pseudohyphae are produced. Ascospores are observed on agar acetate medium after 15 days at $27{ }^{\circ} \mathrm{C}$. Asci are persistent and contain one to four spheroidal to ovoid ascospores that may appear smooth (Fig. 2b). Ascosporulation may be preceded by conjugation between two cells and many cells show the 'dumbbell' configuration typical of Zygosaccharomyces species. On WL agar, after 7 days of incubation at $27^{\circ} \mathrm{C}$, colonies are small, opaque and raised; colony margins are smooth and regular.

Ferments only glucose and fructose, but not sucrose, maltose or trehalose. Assimilates glucose, glycerol, D-sorbitol, 

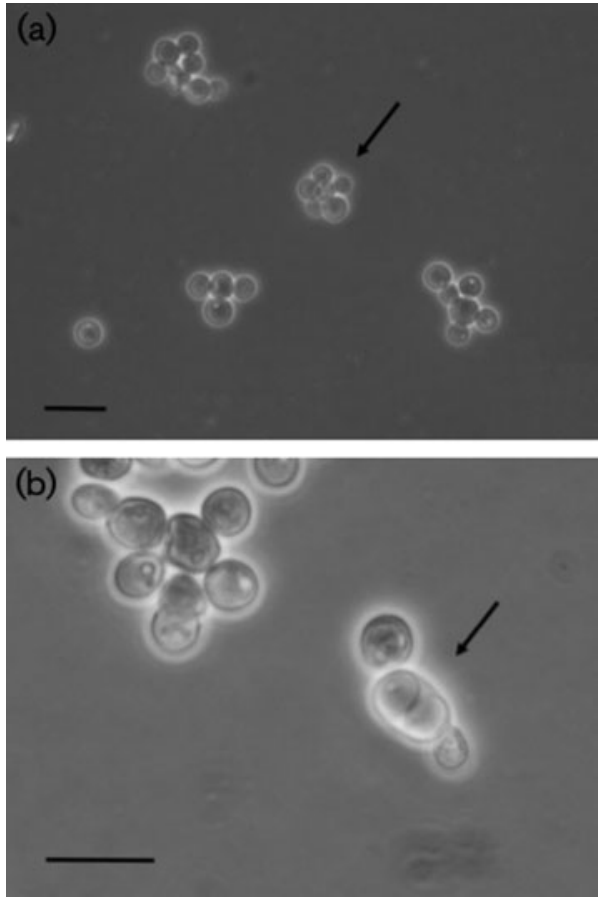

Fig. 2. Photomicrographs of budding cells (indicated by arrows) of Z. gambellarensis ZOO3-5 $5^{\top}$ grown at $27{ }^{\circ} \mathrm{C}$ for 3 days on $5 \%$ malt extract agar medium (a) and ascospores (indicated by arrows) of Z. gambellarensis ZO03-5 $5^{\top}$ grown at $27^{\circ} \mathrm{C}$ for 15 days on agar acetate medium (b). Bars, $10 \mu \mathrm{m}$.

D-galactose, sucrose, trehalose, maltose, adonitol and D-xylose. Cellobiose, lactose, raffinose, melezitose, L-arabinose, $N$-acetyl-D-glucosamine, methyl $\alpha$-D-glucopyranoside, inositol, xylitol, D-mannitol, sodium D-gluconate, DL-lactate, citrate, melibiose, L-arabinose, D-ribose, L-rhamnose, methanol, ethanol, meso-erythritol and calcium-2-ketogluconate are not assimilated. Growth occurs in the presence of $400 \mathrm{~g}$ glucose $1^{-1}$.

The type strain is ZO03-5 $5^{\mathrm{T}}\left(=\mathrm{CBS} 12191^{\mathrm{T}}=\right.$ MUCL $\left.53393^{\mathrm{T}}\right)$.

\section{ACKNOWLEDGEMENTS}

The authors thank Consorzio per la Tutela dei Vini D.O.C. di Gambellara, Camera di Commercio di Vicenza, Provincia di Vicenza, and Banca Popolare di Vicenza for financial support of this research. Authors extend their appreciation to the Gambellara winemakers for providing wine samples.

\section{REFERENCES}

Beuchat, L. R. (1993). Selective media for detecting and enumerating foodborne yeasts. Int J Food Microbiol 19, 1-14.

Ciani, M., Comitini, F., Mannazzu, I. \& Domizio, P. (2010). Controlled mixed culture fermentation: a new perspective on the use of non-Saccharomyces yeasts in winemaking. FEM Yeast Res 10, $123-133$.
Cocolin, L., Bisson, L. F. \& Mills, D. A. (2000). Direct profiling of the yeast dynamics in wine fermentations. FEMS Microbiol Lett 189, 8187.

Donèche, B. J. (1993). Botrytized wines. In Wine Microbiology and Biotechnology, pp. 327-351. Edited by G. H. Fleet. Chur, Switzerland: Harwood Academic Publishers.

Felsenstein, J. (1985). Confidence limits on phylogenies: an approach using the bootstrap. Evolution 39, 783-791.

Fleet, G. H. (1998). The microbiology of alcoholic beverages. In Microbiology of Fermented Foods, 2nd edn, vol. 1, pp. 217-262. Edited by B. J. B. Wood. London: Blackie Academic \& Professional.

Fleet, G. H., Lafon-Lafourcade, S. \& Ribéreau-Gayon, P. (1984). Evolution of yeasts and lactic Acid bacteria during fermentation and storage of bordeaux wines. Appl Environ Microbiol 48, 1034-1038.

Fugelsang, K. C. (1996). Zygosaccharomyces bailii: a spoilage yeast isolated from wine. Technical bulletin 960804. Fresno, CA: California Agricultural Technology Institute.

Gazzetta Ufficiale della Repubblica Italiana (1970). Decreto del Presidente della Repubblica, 26/03/1970. Riconoscimento della denominazione di origine controllata del vino «Gambellara» ed approvazione del relativo disciplinare di produzione, no. 132 (29/5/ 1970), pp. 3435-3438.

Jolly, N. P., Augustyn, O. P. H. \& Pretorius, I. S. (2006). The role and use of non-Saccharomyces yeasts in wine production. S Afr J Enol Vitic 27, 15-39.

Kämpfer, P., Buczolits, S., Albrecht, A., Busse, H.-J. \& Stackebrandt, E. (2003). Towards a standardized format for the description of a novel species (of an established genus): Ochrobactrum gallinifaecis sp. nov. Int $J$ Syst Evol Microbiol 53, 893-896.

Kurtzman, C. P. (2003). Phylogenetic circumscription of Saccharomyces, Kluyveromyces and other members of the Saccharomycetaceae, and the proposal of the new genera Lachancea, Nakaseomyces, Naumovia, Vanderwaltozyma and Zygotorulaspora. FEM Yeast Res 4, 233-245.

Kurtzman, C. P. (2011). Phylogeny of the ascomycetous yeasts and the renaming of Pichia anomala to Wickerhamomyces anomalus. Antonie van Leeuwenhoek 99, 13-23.

Kurtzman, C. P. \& Fell, J. W. (editors) (1998). The Yeasts: a Taxonomic Study, 4th edn. Amsterdam: Elsevier.

Kurtzman, C. P. \& Robnett, C. J. (1998). Identification and phylogeny of ascomycetous yeasts from analysis of nuclear large subunit (26S) ribosomal DNA partial sequences. Antonie van Leeuwenhoek 73, 331371.

Larkin, M. A., Blackshields, G., Brown, N. P., Chenna, R., McGettigan, P. A., McWilliam, H., Valentin, F., Wallace, I. M., Wilm, A. \& other authors (2007). CLUSTAL W and CLUSTAL_X version 2.0. Bioinformatics 23, 2947-2948.

Mills, D. A., Johannsen, E. A. \& Cocolin, L. (2002). Yeast diversity and persistence in botrytis-affected wine fermentations. Appl Environ Microbiol 68, 4884-4893.

Nei, M. \& Kumar, S. (2000). Molecular Evolution and Phylogenetics. New York, USA: Oxford University Press.

Parapouli, M., Hatziloukas, E., Drainas, C. \& Perisynakis, A. (2010). The effect of Debina grapevine indigenous yeast strains of Metschnikowia and Saccharomyces on wine flavour. J Ind Microbiol Biotechnol 37, 85-93.

Ribéreau-Gayon, P., Dubourdieu, D., Donèche, B. \& Lonvaud, A. (2006). Cytology, taxonomy and ecology of grape and wine yeasts. In Handbook of Enology. The Microbiology of Wine and Vinifications, vol. 1, pp. 1-51. Edited by P. Ribéreau-Gayon, D. Dubourdieu, B. Donèche \& A. Lonvaud. Chichester, UK: Wiley. 
Rosa, C. A. \& Lachance, M.-A. (2005). Zygosaccharomyces machadoi sp. n., a yeast species isolated from a nest of the stingless bee Tetragonisca angustula. Lundiana 6 (Suppl.), 27-29.

Saitou, N. \& Nei, M. (1987). The neighbor-joining method: a new method for reconstructing phylogenetic trees. Mol Biol Evol 4, 406-425.

Steels, H., Bond, C. J., Collins, M. D., Roberts, I. N., Stratford, M. \& James, S. A. (1999). Zygosaccharomyces lentus sp. nov., a new member of the yeast genus Zygosaccharomyces Barker. Int J Syst Bacteriol 49, 319-327.

Stratford, M. (2006). Food and beverage spoilage yeasts. In The Yeast Handbook. Yeasts in Food and Beverages, vol. 2, pp. 335-379. Edited by A. Querol \& G. Fleet. Germany: Springer-Verlag.
Tamura, K., Dudley, J., Nei, M. \& Kumar, S. (2007). MEGA4: Molecular Evolutionary Genetics Analysis (MEGA) software version 4.0. Mol Biol Evol 24, 1596-1599.

Tofalo, R., Chaves-López, C., Di Fabio, F., Schirone, M., Felis, G. E., Torriani, S., Paparella, A. \& Suzzi, G. (2009). Molecular identification and osmotolerant profile of wine yeasts that ferment a high sugar grape must. Int J Food Microbiol 130, 179-187.

Yarrow, D. (1998). Methods for the isolation, maintenance and identification of yeasts. In The Yeasts, a Taxonomic Study, 4th edn, pp. 77-100. Edited by C. P. Kurtzman \& J. W. Fell. Amsterdam: Elsevier Science Publishers. 